\title{
Brain over Brawn: Shared Beliefs and Presumptions in Chinese and Western Strategemata
}

Que l'esprit dépasse la force: des présupposés communs aux traditions chinoise et occidentale dans les traités de stratagèmes

以智取勝: 中西軍事戰略思想中共同的信念與假設常有人聲稱“西方的 戰爭之道”

David A. Graff

\section{OpenEdition Journals}

\section{Electronic version}

URL: http://journals.openedition.org/extremeorient/371

DOI: 10.4000/extremeorient.371

ISSN: 2108-7105

\section{Publisher}

Presses universitaires de Vincennes

\section{Printed version}

Date of publication: 1 November 2014

Number of pages: $47-64$

ISBN: 978-2-84292-414-0

ISSN: 0754-5010

\section{Electronic reference}

David A. Graff, "Brain over Brawn: Shared Beliefs and Presumptions in Chinese and Western Strategemata », Extrême-Orient Extrême-Occident [Online], 38 | 2014, Online since 01 January 2017, connection on 28 November 2019. URL : http://journals.openedition.org/extremeorient/371 ; DOI : 10.4000/extremeorient.371 


\title{
Brain over Brawn: Shared Beliefs and Presumptions in Chinese and Western Strategemata
}

\author{
David A. Graff
}

The claim has often been made that there is a unique and distinctive "Western Way of War" that differs fundamentally from the military thought and practice of China and other non-Western cultures. This view, especially prevalent in the United States military in recent years, is mirrored by the claims of Chinese military intellectuals regarding the uniqueness (and superiority) of their own country's ancient tradition of strategic thought. ${ }^{1}$

This article addresses a single aspect of this much larger problem by comparing the West's classical tradition of strategemata with the corresponding Chinese tradition. Proponents of the "Western Way of War" have drawn a sharp contrast between a direct, straightforward Western approach and an "Oriental" way of war characterized by evasion and trickery. ${ }^{2}$ This contrast is supported by the facile juxtaposition of Sunzi's famous dictum that "Warfare is a way of deception" with Carl von Clausewitz's brusque dismissal of the utility of cunning in war: "To prepare a sham action with sufficient thoroughness to impress an enemy requires a considerable expenditure of time and effort, and the costs increase with the scale of the deception. Normally they call for more than can be spared, and consequently so-called strategic feints rarely have the desired effect." ${ }^{3}$ Yet Clausewitz, writing a mere two hundred years ago, is not necessarily the best spokesman for a military tradition putatively covering

1. With regard to the US, see Porter (2009): 17 sq. In the academic year 2008-2009, the Command and General Staff Officers Course at Fort Leavenworth included a curricular "block" entitled "Rise of the Western Way of War," with Geoffrey Parker's Cambridge History of Warfare - which embraces the WWW concept - as one of its core readings. Many other examples could easily be added. For the Chinese side, see Sawyer (2007): 328-331, and Peng and Yao (eds.) (2005): 87-93, 128.

2. Hanson (1990): 222-228; Keegan (1993): 202, 221, 244, 332-333, 387-388.

3. Clausewitz (1984): 203. 
more than twenty-five centuries, nor is he the most apt comparison with a Chinese thinker of much greater antiquity.

Eschewing the apples-to-oranges comparison of Sunzi and Clausewitz, this article examines ancient and early medieval writings that directly address the application of cunning in war. From the Western side, the objects of analysis are the classical compendia of Frontinus, Onasander, and Polyaenus - all dating from the first two centuries of the Common Era - and the later Byzantine military treatises, especially the Strategikon dating from circa 600 $\mathrm{CE}$ and conventionally attributed to the emperor Maurikios. On the Chinese side, attention is directed to the ancient military treatises (of which Sunzi bingfa is the best known), the early dynastic histories, and Du You's Tong dian, an important encyclopedia dating from the late eighth century CE. It will be seen that for all practical intents and purposes the two corpora form a single corpus - that is, they include essentially the same range of cunning stratagems that appear to derive from common or shared assumptions about human psychology.

\section{Traditions of cunning}

In both the Chinese and the Greco-Byzantine traditions, the ideal was to employ strategy and cunning to defeat the enemy without having to fight a battle. One of the most famous passages in Sunzi bingfa, the assertion that the acme of skill is not victory in battle but rather to subdue the enemy without fighting, has a parallel in the Strategikon: "Strategy makes use of times and places, surprises and various tricks to outwit the enemy with the idea of achieving its objectives even without actual fighting." ${ }_{4}$ In this regard, the Byzantine text is also in keeping with the earlier Greek literature on the art of war, which sought "to avoid the risks of battle except under the most favorable circumstances, and to use every conceivable nonmilitary device to improve the likelihood of accomplishing one's purposes with the minimum of losses." 5

The valorization of cunning, of the use of one's wits and tongue and to achieve one's aims, had a venerable pedigree in the Greek cultural traditions inherited by Byzantium, reaching back as far as the wily Odysseus in the Illiad and the Odyssey. The Greeks called the form of cunning intelligence exemplified by the inventor of the Trojan horse metis. According to Lisa Raphals, "This mode of intelligence embraces a set of skills and mental attitudes

4. Dennis (1984): 23; Mair (2007): 85; Guo (ed.) (1962): 34.

5. Kaegi (1983): 12. 
that range from wisdom, forethought, keen attention, and resourcefulness to subtle indirection, craft, deception, and cunning. It relies on skill, strategy, and a general knack for handling whatever comes along." ${ }^{6}$ What Raphals has called "metic intelligence" was often put to work in early Greek warfare. One classicist has counted more than 140 examples of trickery and deception ranging from the eighth century to the fourth century BCE. ${ }^{7}$ To pick only one example, at the battle of Sepeia early in the fifth century BCE, Kleomenes of Sparta surprised and defeated the Argives after pretending to disband his troops for breakfast, with the result that a reported 6,000 Argives were slain. Another modern scholar has found that ambushes, night raids, and attacks on camps were quite common in Greek warfare: "An appreciation of cunning was as much a constant factor as admiration for fair and open combat." And in ancient times no less an authority than Xenophon asserted, in his Cavalry Commander, that "in war nothing is more profitable than deceit." 8 The Romans sometimes professed to disdain the Greek emphasis on cleverness in war, but their actual behavior tended to conform to the precedents set by the Greeks. ${ }^{9}$ As for the Byzantines, the Strategikon maintains that deception "is often helpful in warfare" and offers various means of misleading the enemy; in order to retreat safely, for example, one should "build a fire in one place and quietly go off to another; the enemy will head for the fire." And one should not allow oneself to be deceived by the enemy's humane acts, by his pretending to retreat, or by false reports brought by his deserters. ${ }^{10}$

The observations of classicist Everett L. Wheeler that the ancient Greeks "seem to expect trickery and to take delight in it" and believed that "one should be prepared for it and able to deceive a deceiver" may be applied with equal force to the ancient Chinese - if not to straitlaced Confucian scholars, then certainly to the authors of military texts and works on rhetoric and persuasion, as well as a great many practical politicians and statesmen. ${ }^{11}$ Sunzi bingfa pronounces unequivocally that "Warfare is a way of deception" and offers a variety of specific suggestions for misleading the enemy. ${ }^{12}$ Other classical military texts such as the Liu tao also place great emphasis on deceit, and the

6. Raphals (1992): xi-xii. The discussion of metis in Jullien (2004): 8 is also helpful.

7. Krentz (Wees) (2000): 183-199.

8. Wees (2004): 131, 133.

9. Wheeler (1988): 16, 24, 102, and 110.

10. Dennis (1984): 80-83, 89 .

11. Wheeler (1988): 108-109, and Raphals (1992): 7, 101. Raphals notes that the Chinese military texts stress "metic intelligence" (p. 103). Even the Confucian scholar Mencius is reported to have practiced deception on some occasions.

12. Mair (2007): 78; Guo (ed.) (1962): 12. 
Zhanguoce, a collection of stories about the politico-military skullduggery of the Warring States collected in the Western Han period, presents hundreds of cunning and elaborate stratagems for its readers' delectation. ${ }^{13}$ In the historical literature from the Zuo zhuan and the Shiji onward, battle narratives typically focus on elaborate stratagems while neglecting the more mundane aspects of combat and maneuver. For example, one account of the battle fought between the rival warlords Li Mi and Wang Shichong in the Mang Hills northeast of Luoyang in the autumn of $618 \mathrm{CE}$ tells us that outcome was decided by a ploy of Wang's. At the height of the action, he had a man in his own army who resembled Li Mi trussed up and brought out, and then raised the cry that his opponent had been captured - causing a panic in Li Mi's army. ${ }^{14}$ On another occasion a few years later, the Tang general Chai Shao is supposed to have distracted his Tangut and Tuyuhun foes by having two girls dance to musical accompaniment while his cavalry circled around to their rear. This sort of thing is commonplace in traditional Chinese battle narratives; though it may not have loomed quite so large in the actual warfare of the time, it does tells us something about cultural ideals and what educated, literate men thought war ought to be like.

\section{Shared stratagems}

"Stratagem" has been defined by Wheeler as "a strategic or tactical act of trickery, deceit, or cunning in military affairs especially war, whereby one attempts to gain psychological or material advantage over an opponent, to neutralize some part of an opponent's superiority, to minimize one's own expenditure of resources, or to restore the morale and physical state of one's own forces." ${ }^{15}$ The Greco-Roman-Byzantine textual tradition includes a great many specific examples of such devices, some of them gathered in collections of strategemata such as those of Frontinus and Polyaenus, others appearing in military manuals and historical works. In general, there is both a high degree of continuity within this tradition and a very high level of congruence with the

13. See, for example, the "Wen fa" chapter of Liu tao, in Xu (ed.) (1986): 88-90, and Sawyer (1993): 56 sq. Also, Crump (1996).

14. Ouyang, Song (1975): 3684. The original source for this anecdote is probably the now lost Huguan lu; see Sima Guang's comments in Zizhi tongjian: Sima Guang (1956): 5811. As I discuss in detail in Graff (1995): 307-312, there are both textual and practical reasons for doubting the authenticity of this story.

15. Wheeler (1988): x $s q$. 
Chinese textual tradition which is itself marked by continuity. Not only do we find the same emphasis on deception and the exploitation of psychology to achieve one's aims, but we also find the same schemes and devices employed at both ends of the Eurasian landmass. Both the "Military Methods" of the early Tang general Li Jing (preserved in Du You's Tong dian) and an anonymous Byzantine text probably dating from the ninth century recommend that if one must fight a battle when one is weaker than the enemy, it is best to start the battle near sunset so that darkness will impede pursuit in the event of a defeat. ${ }^{16}$ Li Jing, Onasander, and the author of the Strategikon were all aware that at night campfires could be manipulated to deceive the enemy as to one's whereabouts and intentions. ${ }^{17}$ Western and Chinese texts are both familiar with the idea of distracting the enemy with a feint or demonstration, something that could be done at either the tactical or strategic level. In China the idea first appears in Sunzi bingfa and in the Tang dynasty is given the following formulation by Du You: "Announce that you will strike in the east, but actually strike in the west." ${ }^{18}$ In the Western tradition, Polyaenus reports that on one occasion the fourth-century BCE Athenian general Iphicrates was able to pass an enemy position safely at night by blowing his trumpets at one end of the line and then marching quietly past at the other end. ${ }^{19} \mathrm{He}$ also recounts how another Athenian general, Demosthenes, took Pylos during the Peloponnesian War. Finding the place too strongly garrisoned by the Spartans, Demosthenes feinted against Acra - and when the Spartans marched off to defend that place, he returned to capture Pylos. ${ }^{20}$ This is a close fit with the classic Chinese stratagem of "besieging Wei to rescue Zhao" (wei Wei jiu Zhao), defined as subduing "the enemy indirectly by threatening one of his unprotected weak spots," which makes its first appearance in Sima Qian's Shiji biography of Sun Bin in connection with a campaign involving the states of Qi, Wei, and Zhao in the mid-fourth century BCE. ${ }^{21}$ The distractions could sometimes be elaborate

16. Du (1988): 3840 sq.; “Anonymous Byzantine" in Dennis (1985): 105, which spells out the logic more fully than the Chinese text.

17. Du (1988): 3840 sq.; Illinois Greek Club (1923): 419; Dennis (1984): 81. The Chinese use of campfires to delude the enemy reaches back at least as far as the Maling campaign of 341 BCE, as described in Sima Qian's Shiji biography of the strategist Sun Bin. See Sima Qian (1959): 2164, translated in Nienhauser (ed.) (1995): 41.

18. Senger (1991): 75-77; Mair (2207): 96 sq.; Du (1988): 3914.

19. Polyaenus (1974): 102.

20. Polyaenus (1974): 95 sq.

21. Senger (1991): 33-37. Sun Bin was seeking to relieve Wei's siege of the Zhao capital (not capture it himself) by striking at Wei's own capital, and in this case the pithy fourcharacter expression was not coined until the Ming dynasty, in Luo Guanzhong's novel 
and even outrageous. On one occasion in 193 BCE, in an episode recorded by Frontinus that is reminiscent of Chai Shao's use of dancing girls against the Tangut and Tuyuhun eight hundred years later, Rome's auxiliary Numidian cavalry pretended to fall from their horses and "engage in ridiculous antics" to throw their Ligurian opponents off guard. The Ligurians, "breaking ranks at the novel sight, gave themselves up completely to the enjoyment of the show," with the result that the Numidians were able to break through their line. ${ }^{22}$

In both the Chinese and Greco-Roman-Byzantine traditions, military men are told to be alert to the enemy's wiles and are even given specific tips that might alert them to attempts at deception. Frontinus tells us that when fighting the Etruscans around 280 BCE, Q. Aemilius Paulus "saw afar off a flock of birds rise in somewhat startled flight from a forest, and realized that some treachery was lurking there, both because the birds had risen in alarm and at the same time in great numbers." Sure enough, his scouts found ten thousand enemy soldiers lying in ambush there. Polyaenus records a Greek example of the same thing, and this, too, is repeated by Frontinus. ${ }^{23}$ On the Chinese side, Sunzi bingfa (ch.9) warns us, "when birds fly up, there is an ambush." 24

Many stratagems were based on assumptions about human behavior and what we would today call mass psychology: when confronted with a stimulus $\mathrm{X}$, men will respond by doing Y. In both East and West, these assumptions - and the stratagems derived from them - were essentially the same. Wang Shichong's ploy involving the man who resembled Li Mi has a close, if not exact, counterpart in the pages of Onasander: "... when the leader of the enemy is some distance away either on one wing or holding the centre, [the general] should call out, 'The general of the enemy had been killed,' or 'the king,' or whoever it may be." This, we are assured, will encourage one's own troops and cause the enemy soldiers to lose heart and perhaps even flee in panic. ${ }^{25}$ Frontinus recounts that in 280 BCE the Roman general Valerius Laevinus spread a false rumor that he had slain his opponent, Pyrrhus of Epirus. Pyrrhus' men were "panic-stricken at the falsehood, and thinking that they had been rendered helpless by the death of their commander, betook themselves in

San guo yanyi. The original story can be found in Sima Qian (1959): 2163, translated in Nienhauser (ed.) (1995): 40.

22. Frontinus (1980): 45.

23. Frontinus (1980): 21, 23; Polyaenus (1974): 92.

24. Mair (2007): 110; Guo (ed.) (1962): 153.

25. Illinois Greek Club (1923): 463. 
terror back to camp." ${ }^{26}$ This ploy would have been even more effective during the medieval period, when armies were often held together by personal bonds between leaders and followers and the sight of a leader's death was almost always sufficient to precipitate an immediate rout. ${ }^{27}$

\section{Psychological manipulation}

In both China and the Mediterranean world, there was an understanding that morale was highly situational, that what soldiers could (and could not) be expected to do depended very much on the location and the context. Both Sunzi bingfa and the Strategikon make the point that soldiers deep in enemy territory will fight with more determination than in their own homeland, with the Byzantine manual spelling out the psychological assumptions left implicit by Sunzi: men will fight more aggressively when their personal safety depends on success in fighting, and where there are no friendly strongholds to offer them refuge. ${ }^{28}$ Similarly, the ancient Chinese military classic, the Strategikon, and the tenth-century Byzantine treatise "On Skirmishing" agree that the best time to attack an invading army is on its return road, when it is laden down with booty and its soldiers are already thinking of home and thus psychologically unprepared for further combat. ${ }^{29}$ In general, it was always and everywhere considered advisable to confront an exhausted enemy with troops who were fresh and well rested. ${ }^{30}$

In both traditions, the soldiers were to be manipulated rather than exhorted. The author of the Strategikon advises the general not to share his plans with his

26. Frontinus (1980): 129. Polyaenus has a similar stratagem aimed at the same effect, with the Athenian general Myronides shouting on the right wing that the left has been victorious, encouraging his own men and demoralizing the Thebans opposing them. See Polyaenus (1974): 32.

27. McGeer (1995): 307 sq. McGeer is speaking of the Byzantines and their opponents, but the general point can be extended to many Chinese armies - especially those involved in civil conflicts such as that which surrounded the Sui-Tang transition.

28. Dennis (1984): 83; Mair (2007): 117 sq.; Guo (ed.) (1962): 181-189.

29. Dennis (1984): 107 sq.; Dennis (1985): 157-159; Mair (2007): 103 - but note that the Chinese treatise appears to offer contradictory advice since one is not supposed to intercept an army returning home (page 104). For Chinese text, see Guo (ed.) (1962): 119-131.

30. Polyaenus (1974): 126; Mair (2007): 95; Guo (ed.) (1962): 82 sq.; Du (1988): 3954 sq, 4061 sq. 
troops, a point already made a millennium or so earlier in the Sunzi bingfa. ${ }^{31}$ In both China and the ancient Mediterranean world auspices and omens were taken very seriously by military writers, not as guides to action but rather as powerful influences on the soldiers' morale. The approach recommended by the most influential of the Chinese military manuals was to ban unofficial prognostication that might give rise to doubts among the troops. In a famous passage, Sunzi bingfa advises the general to "prohibit talk of omens and banish doubts," advice that was echoed and expanded upon by Li Jing in the Tang: "If one speaks of Dao or Buddha, or prays to ghosts and spirits, or performs divination with yin and yang, or spreads false talk of auspicious and inauspicious omens, thereby shaking the morale of the masses, execute him and those who run back and forth to carry on conversations with him." 32 Some Western commanders would have agreed; campaigning in Spain in 134 BCE, the Roman Scipio Aemilianus expelled all the soothsayers from his camp (along with traders and prostitutes) in order to restore discipline. ${ }^{33}$ In general, however, the Greco-Roman tradition tended to take a more positive approach, advising the use of favorable omens to raise the spirits of the troops. According to Onasander, "The general should neither lead his army on a journey, nor marshal it for battle, without first making a sacrifice; in fact, official sacrifices and diviners should accompany him." Nothing should be undertaken until the omens are favorable, for soldiers "are far more courageous when they believe they are facing dangers with the good will of the gods..." 34

This is taken a step further by Frontinus and Polyaenus, who present with evident approval - numerous historical instances of favorable omens deliberately faked. The fourth-century BCE Theban general Epaminondas, for example, had his troops make vows at the temple of Hercules after he had secretly arranged for the priests to polish some rusty arms and place them beside the god's statue. Taken to be a sign of supernatural assistance, this greatly increased morale and the Thebans went on to defeat the Spartans. ${ }^{35}$ The historical sources make it quite clear that some Chinese generals also saw the advantage in this approach, whatever Sunzi might say to the contrary.

31. Dennis (1984): 88 sq.; Mair (2007): 121, 123; Guo (ed.) (1962): 199 sq., 208.

32. Du (1988): 3823;Mair (2007): 120; Guo (ed.) (1962): 195.

33. Sidebottom (2004): 78.

34. Illinois Greek Club (1923): 429. There is considerable evidence that Greek armies of the fifth and fourth centuries BCE were reluctant to take action in the absence of favorable auspices; see Bowden (2005): 5 sq.

35. Polyaenus (1974): 67; other examples can be found on pages 59, 68 sq., $180 s q$., and 331. Also see Frontinus (1980): 75-79. 
Before leading his troops out of Luoyang to do battle with $\mathrm{Li} \mathrm{Mi}$ in 618, Wang Shichong claimed that the Duke of Zhou, the ancient statesman who had founded that city more than fifteen hundred years earlier, had appeared to him in a dream. On this pretext, he established a shrine for the Duke by the bank of the Luo River and had shamans announce the Duke's intention: If the soldiers went out to fight Li Mi they would certainly win great merit, but if they refused they would all die of a pestilence. ${ }^{36} \mathrm{~A}$ Jin-dynasty general named $\mathrm{Li} \mathrm{Ju}$ had made use of almost exactly the same device to nerve the defenders of Xingyang to make a surprise attack on a Xiongnu army in $317 \mathrm{CE}$, except that on that occasion the shamans claimed to be interpreting the will of Zichan, another ancient statesman who happened to be associated with the area around Xingyang. ${ }^{37}$ In this regard, the Chinese - ancient and medieval - had more in common with Mediterranean antiquity than with the Byzantines, in whose armies Christian prayers and liturgies had supplanted the ancient omens and auspices. ${ }^{38}$

One did not have to be a Christian to recognize the beneficial impact that solicitous treatment of the wounded and the dead might have on the morale of the troops and their willingness to fight. The ancient Chinese military literature included an anecdote telling how $\mathrm{Wu} \mathrm{Qi}$, a renowned general of the fifth century BCE, went so far as to suck the pus from his men's abscesses in order to secure their loyalty and affection. ${ }^{39}$ By the early Tang dynasty, this concern for the men was no longer personal but had been thoroughly bureaucratized. According to Li Jing,

"In all cases when there are invalids in the encampments, in each encampment designate one officer to inspect the thick soups and porridges being fed to them and to lead them when the army is on the march. A comprehensive report on those men who have just fallen ill and those who have been lost to sickness is made to the commander every morning, and a medical man is ordered to make the rounds of the encampment with medicine to cure the sick." 40

36. This episode can be found in Wei Zheng et al. (1973): 1897, and Du (1988): 4016. A more complex and probably later version is in Ouyang, Song (1975): 3692, and Sima Guang (1956): 5809.

37. Fang Xuanling et al. (1974): 131, 1707.

38. For the role of religion in the Byzantine military, see Goubert (1947): 495-500.

39. This story can be found in the Shi ji biography of Wu Qi; see Sima Qian (1959): 42, translated in Nienhauser (ed.) (1995): 42.

40. Du (1988): $3819 s q$. 
Although it might not be possible to provide an animal sacrifice and the ritually prescribed double coffin, the fallen were to receive a decent burial at the very least:

"If a man dies in enemy territory, the libation is made with a single cup of wine, the grave is four feet deep, and his commanding officer sends men to wail by the grave. For a man who dies in the interior and not in enemy territory, the sacrifice and wailing are as previously described but [the body] is sent to [the man's registered] place of origin." ${ }^{41}$

The practical advantages to be gained from such observances, implicit in these passages from Li Jing, is made explicit in the Strategikon: "After battle the general should give prompt attention to the wounded and see to burying the dead. Not only is this a religious duty, but it greatly helps the morale of the living." ${ }^{2}$

\section{Deadly ground: a point of disagreement}

The Chinese and the Byzantines did not always see eye to eye, however, nor did they interpret their inherited traditions in quite the same way. One area where divergence is especially apparent is the set of related problems that the Chinese military classics labeled "deadly ground" (si di) and "the desperate bandit" (qiong kou). The basic idea, the psychological supposition underpinning the stratagem, is that troops who have been surrounded or have their backs to the wall with no hope of escape are especially dangerous foes because they will fight with a reckless courage born of desperation. Hence, the Sunzi bingfa maintains that "desperate bandits" should not be pressed; encircled enemies must be allowed a way out so they may choose to flee rather than fight. ${ }^{43} \mathrm{Li}$ Jing accepted the same logic in the early Tang: "If the enemy is in deadly ground, with no place to rely on to make himself secure, where his provisions are already used up, and relieving troops cannot reach him, he is called a 'desperate bandit'... Deploy but do not accept battle - this is the method for defeating the enemy's plan." ${ }^{44}$ Sunzi seems to have understood "deadly ground" in situational rather than geographical terms, but his secondcentury CE commentator, the late-Han warlord Cao Cao, was happy to fill in the picture with concrete terrain features. "In front, there are high mountains;

41. Du (1988): 3820 .

42. Dennis (1984): 70; also see page 86.

43. Mair (2007): 104; Guo (ed.) (1962): 128-31.

44. $\mathrm{Du}(1988): 4087$. 
behind, there is a great river. If one tries to advance, one cannot; if one tries to retreat there is an obstruction." ${ }^{45}$ The idea of giving a cornered enemy a way out is no less prominent in the classical Western tradition than in the Chinese; it is mentioned, in some cases repeatedly, by Frontinus, Onasander, Polyaenus, and Vegetius. Polyaenus tells us that the Spartan king Agesilaus, after his victory at Coronaea in $394 \mathrm{BCE}$, was told that the surviving Athenians had taken refuge in the temple of Athena. His reply? "Let them go wherever they are inclined; for nothing can be attended with greater danger, than an engagement to which the enemy is forced by despair." 46 According to Frontinus, "Scipio Africanus used to say that a road not only ought to be afforded to the enemy for flight, but that it ought even to be paved." ${ }^{47}$ The idea carried over seamlessly into the Byzantine tradition, appearing in the Strategikon, in the anonymous treatise now thought to have been written by Syrianos in the ninth century, and in the tenth-century treatise "On Skirmishing" written at the behest of Nikephoros Phokas. ${ }^{48}$

A corollary of the stratagem of leaving the enemy a way out is to deliberately deploy one's own army in a place of no escape in order to unlock the same sort of primal ferocity. This ploy is perhaps most fully articulated in Sunzi bingfa: "Throw your forces into positions from which there is no outlet; there they may die, but they will not be put to rout. Since they are ready for death, the officers and men will exert themselves to the utmost." 49 If one occupies "deadly ground," one should fight - and can expect to do so with a psychological advantage. ${ }^{50}$ The stratagem of placing one's soldiers in a desperate situation - especially attractive if they were relatively poor soldiers was employed repeatedly in Chinese history, most famously by Han Xin at the Jingxing Pass in 205 BC, when he deployed his inferior force with its back to a river to defeat a superior opponent occupying the heights above. ${ }^{51}$ At the battle of Shayuan in 537, Yuwen Tai of the Western Wei deployed his much smaller army with its back against the Wei River and managed to defeat his Eastern Wei rival, Gao Huan. Although Li Jing neither mentions nor recommends this ploy in his "Military Methods," it was used during his lifetime - most notably

45. Guo (ed.) (1962): 185 sq.

46. Polyaenus (1974): 52; also see pages 57 and 101.

47. Frontinus (1980): 315; also see pages 165-169. For other mentions of the concept, see Milner (1993): 101, and Illinois Greek Club (1923): 497.

48. Dennis (1984): 81,91; Dennis (1985): 107, 119, and 235.

49. Mair (2007): 119 sq.; Guo (ed.) (1962): 194.

50. Mair (2007): 105; also see pages 122, 124. Chinese text in Guo (ed.) (1962): 133, 204 sq., 209.

51. Kierman (Kierman, Fairbank) (1974): 56-62. 
against Li Mi at the Mang Hills in the autumn of 618, when the victor, Wang Shichong, copied Han Xin's playbook from Jingxing. ${ }^{52}$

There is nothing uniquely Chinese about this idea. Numerous historical examples of battle plans based on the same psychological assumptions can be found in the Greek and Roman strategemata; here is one from Polyaenus: "Iphicrates having been brought to an engagement in an open plain, where the enemy were much superior in numbers, drew up his army; first opening a trench on his rear: thereby showing them, that by thus having cut off all hopes of retreat, they had nothing left but to conquer or die." ${ }^{53}$ Onasander, however, was less enthusiastic about this approach:

"Generals who destroy their own defenses or cross rivers or who post their armies with steep cliffs or yawning gulfs in their rear in order that the soldiers may either stand and conquer or in their desire to escape be killed, I am not wholly able to praise nor yet to blame, for everything that is ventured rashly is rather the part of recklessness than of wisdom, and has a greater share of luck than of good judgement." 54

The Byzantines appear to have been even less interested in the exploitation of "deadly ground." The deliberate positioning of soldiers in desperate situations is recommended in none of their surviving military treatises, and when, in their actual warfare, Byzantine armies fought from such positions it was not by choice. In the winter of 503-4, for example, an Eastern Roman army deployed with its back to the River Nymphius and defeated its Persian pursuers, but it chose to fight only because its retreat was blocked by the river. ${ }^{55}$ There is some evidence that in Byzantine eyes such ploys were associated with barbarians and were regarded as likely to rebound upon their users. According to the early seventh-century historian Theophylact Simocatta, before the battle of Solachon (in 586 or 587) the Persian commander ordered his men to destroy the skin flasks they had filled with water, to make it clear to them that they would either die of thirst or fight their way through the Byzantine battle line to drink from the River Arzamon. "Nor indeed did his boldness stand him in

52. The battle of the Mang Hills is described in Sima Guang (1956): $5810 s q . ;$ et al. (1973): 1632 and 1897; and in Graff (1995): 289-317.

53. Polyaenus (1974): 104, with spelling modernized; also see pages 32, 57, 137, 196, 215 , 216, 242, and 301; and Frontinus (1980): 81.

54. Illinois Greek Club (1923): 475. The author really does go back and forth on this; two pages later he writes, "If the destruction of one's army is evident, except through the use of some daring strategy, and if the destruction of the enemy by defeat is also evident, then I do not think a general would be at fault in cutting off the retreat of his own army." (page 477)

55. Greatrex (1998): 110. 
good stead," commented Theophylact, "for it is foolish, by trusting the dice of Fortune, to be confident at the heights of peril, and to glean favourable outcomes from previous errors." In the event, the Persians were defeated and suffered horribly from lack of water during their subsequent retreat. ${ }^{56}$

The Byzantine aversion to "deadly ground" stratagems probably owed as much to limited reserves of trained manpower and a reluctance to squander them in risky ventures as to religious beliefs and scruples. As the inheritor of the military traditions of the Principate, the Eastern Roman army of the sixth and seventh centuries was made up largely of men who were in theory, and to a considerable extent in practice as well, professional soldiers - professional in the sense that they enlisted for long periods of time, served for pay, and relied on soldiering as their main or even their sole source of income. ${ }^{57}$ Such men were expensive, and they could not be easily replaced. Civilians were untrained and, in the interest of public order, not allowed to own weapons. Some weapons were stored in city armories so that the populace might assist in the defense in the event of a siege, but apart from this sort of special situation the Eastern Roman state appears never to have contemplated the short-term conscription of large numbers of civilians to meet even its most pressing military needs. ${ }^{58}$ The Chinese, with their generally less "professional" armies, had access to vastly greater manpower resources from which to make good any losses. During the early years of the Tang dynasty for example, the court relied not only on the farmer-soldiers subordinated to several hundred local regimental headquarters (zhechong fu), a sort of "national guard" that may have included about 260,000 men in the second quarter of the seventh century, but also on large numbers of men conscripted on an ad hoc basic for specific military campaigns. ${ }^{59}$ In the context of China's rather different military institutions, "deadly ground" ploys may have been attractive as a way of getting indifferently trained and poorly motivated conscripts to fight at all.

\section{Conclusion}

Despite such discrepancies, likely stemming from differences in material conditions and military institutions, the conventional wisdom about warfare

56. Theophylact (1986): 49.

57. Ahrweiler (Parry, Yapp) (1975): 89.

58. Jones (1964): 1.671; Kaegi (1992): 37, 50, 52, 259 sq.

59. For a more extensive discussion of early Tang military institutions, see Graff (2002): 189-192. The figure of 260,000 is drawn from Lai (1986): 12. 
in China and the Mediterranean world was for the most part quite similar. War was not to be welcomed, but had to be approached with care and caution. In the conduct of war, the emphasis was on rational planning and foresight rather than heroic bravado. Deception and trickery were prized rather than despised, as were any and all devices that might give one an advantage over one's opponent. Although there were some prominent exceptions, the recommended style of generalship in both civilizations was notably unheroic, with generals directing battles from the rear rather then fighting in the front rank. ${ }^{60}$ As the Strategikon puts it, "Superior officers should be stationed in safe places, so they do not dash forward and fall in battle, which would discourage the soldiers." ${ }^{61}$ The Weiliaozi, a Chinese military treatise probably dating from the third century BCE, includes a story about the great general Wu Qi refusing a sword offered him by his subordinates with the explanation, "To command the troops and direct their blades, this is the role of the commander. To wield a single sword is not his role." ${ }^{62}$ In both China and West, the hardearned lessons acquired from past experience were recorded in writing, handed down to later generations, and applied to the conduct of warfare. For the most part, these lessons pointed men in the same direction. As the example of the "deadly ground" ploy suggests, however, the efficacy of particular stratagems is by no means universal, but may instead be linked to social and institutional conditions that are themselves impermanent.

60. Two obvious exceptions are Alexander of Macedon and the second emperor of the Tang dynasty, Li Shimin (Tang Taizong). For Li Shimin's behavior in battle, see Graff (Deist) (2003): 155-167.

61. Dennis (1984): 32 .

62. Lewis (1990): 114; Liu (1975): 109. 


\section{BiBLIOGRAPHY}

AHRweILER Hélène (1975). “L'organisation des campagnes militaires à Byzance.” In V. J. Parry and M. E. Yapp (eds.), War, Technology and Society in the Middle East. London, Oxford University Press.

Bowden Hugh (2005). Classical Athens and the Delphic Oracle: Divination and Democracy. Cambridge, Cambridge University Press.

Clausewitz Carl von (1984). On War, ed. and trans. Michael Howard and Peter Paret. Princeton, NJ, Princeton University Press.

Crump J. I. (trans.) (1996). Chan-kuo Ts'e. Ann Arbor, MI, Center for Chinese Studies, The University of Michigan.

Dennis George T. (trans.) (1984). Maurice's Strategikon: Handbook of Byzantine Military Strategy. Philadelphia, University of Pennsylvania Press.

Dennis George T. (trans.) (1985). Three Byzantine Military Treatises. Washington, DC, Dumbarton Oaks.

Du You (1988). Tong dian. Beijing, Zhonghua shuju.

FANG Xuanling et al. (1974). Jin shu. Beijing, Zhonghua shuju.

Frontinus Sextus Julius (1980). The Stratagems and The Aqueducts of Rome, trans.

Charles E. Bennett. London, William Heinemann Ltd.

Goubert Paul (1947). "Religion et superstitions dans l'armée byzantine à la fin du vi siècle." Orientalia Christiana Periodica, 13.

GrafF David A. (1995). Early T'ang Generalship and the Textual Tradition. Ph.D. diss., Princeton University.

Graff David A. (2002). Medieval Chinese Warfare, 300-900. London and New York, Routledge.

Graff David A. (2003). "Li Shimin and the Representation of Military Leadership in Medieval China." In Rosemarie Deist (ed.), Knight and Samurai: Actions and Images of Elite Warriors in Europe and East Asia. Göppinger Arbeiten zur Germanistik, No. 707. Göppingen, Kümmerle Verlag.

Greatrex Geoffrey (1998). Rome and Persia at War, 502-532. Leeds, Francis Cairns.

Guo Huaruo (ed.) (1962). Shiyi jia zhu Sunzi. Shanghai, Zhonghua shuju.

Hanson Victor Davis (1990). The Western Way of War: Infantry Battle in Classical Greece. New York, Oxford University Press.

Illinois Greek Club (trans.) (1923). Aeneas Tacticus, Asclepiodotus, Onasander. London, William Heinemann.

Jones A. H. M. (1964). The Later Roman Empire, 284-602: A Social, Economic and Administrative Survey. Norman, University of Oklahoma Press.

JulLIEN François (2004). A Treatise on Efficacy: Between Western and Chinese Thinking, trans. Janet Lloyd. Honolulu, University of Hawai'i Press.

KAEgI Walter Emil, Jr. (1983). Some Thoughts on Byzantine Military Strategy. Brookline, MA, Hellenic College Press.

KAEGI Walter E. (1992). Byzantium and the Early Islamic Conquests. Cambridge, Cambridge University Press.

KeEgan John (1993). A History of Warfare. New York, Alfred A. Knopf. 
Kierman Frank A., Jr. (1974). "Phases and Modes of Combat in Early China." In John King Fairbank and Frank A. Kierman, Jr. (eds.), Chinese Ways in Warfare. Cambridge, MA, Harvard University Press.

Krentz Peter (2000). "Deception in Archaic and Classical Greek Warfare." In Hans van Wees (ed.), War and Violence in Ancient Greece. London and Swansea, Duckworth and the Classical Press of Wales.

LaI Swee Fo (1986). The Military and Defense System under the T'ang Dynasty. Ph.D. diss., Princeton University.

LEwIS Mark Edward (1990). Sanctioned Violence in Early China. Albany, State University of New York Press.

Liu Zhongping (ed.) (1975). Weiliaozi jin zhu jin yi. Taipei, Taiwan Commercial Press.

MaIr Victor H. (trans.) (2007). The Art of War: Sun Zi's Military Methods. New York, Columbia University Press.

McGeER Eric (1995). Sowing the Dragon's Teeth: Byzantine Warfare in the Tenth Century. Washington, DC, Dumbarton Oaks.

Milner N. P. (trans.) (1993). Vegetius: Epitome of Military Science. Liverpool, Liverpool University Press.

NiENHAuSER William H., Jr. (ed.) (1995). The Grand Scribe's Records, vol. 7: The Memoirs of Pre-Han China. Bloomington and Indianapolis, Indiana University Press.

Ouyang Xiu and Song Qi (1975). Xin Tang shu. Beijing, Zhonghua shuju.

Peng Guangqian and Yao Youzhi (eds.) (2005). The Science of Military Strategy. Beijing, Military Science Publishing House.

Polyaenus (1974). Stratagems of War, trans. R. Shepherd. Chicago, Ares Publishers.

PORTER Patrick (2009). Military Orientalism: Eastern War Through Western Eyes. New York, Columbia University Press.

RaPHALs Lisa (1992). Knowing Words: Wisdom and Cunning in the Classical Traditions of China and Greece. Ithaca and London, Cornell University Press.

SAwYer Ralph D. (trans.) (1993). The Seven Military Classics of Ancient China. Boulder, CO, Westview Press.

SAWYER Ralph D. (2007). The Tao of Deception: Unorthodox Warfare in Historic and Modern China. New York, Basic Books.

Senger Harro von (1991). The Book of Stratagems. New York, Viking Penguin.

Sidebotтom Harry (2004). Ancient Warfare: A Very Short Introduction. Oxford, Oxford University Press.

Sima Guang (1956). Zizhi tongjian. Beijing, Guji chubanshe.

SimA Qian (1959). Shi ji. Beijing, Zhonghua shuju.

Theophylact Simocatta (1986). The History of Theophylactus Simocatta, trans. Michael and Mary Whitby. Oxford, Clarendon Press.

WeEs Hans van (2004). Greek Warfare: Myths and Realities. London, Gerald Duckworth \& Co. Ltd.

Wer Zheng et al. (1973). Sui shu. Beijing, Zhonghua shuju.

WHEELER Everett L. (1988). Stratagem and the Vocabulary of Military Trickery. Leiden, E. J. Brill.

Xu Peigen (1986). Taigong Liu tao jin zhu jin yi. Taipei, Taiwan Commercial Press. 


\section{GLOSSARY}

Cao Cao 曹操

Chai Shao 柴紹

Du You 杜佑

Gao Huan 高歡

Han (dynasty) 漢

Han Xin 韓信

Huguan lu 壼關録

Jin (dynasty) 晉

Jingxing 井陘

Li Jing 李靖

$\mathrm{Li} \mathrm{Ju}$ 李矩

$\mathrm{Li} \mathrm{Mi}$ 李密

Li Shimin 李世民

Liu tao 六韜

Luo Guanzhong 羅貫中

Luo River 洛水

Luoyang 洛陽

Maling 馬陵

Mang Hills 亡ऍ山

Qi 齊

qiong kou 窮寇

San guo yan yi 三國演義

Shayuan 沙苑

Shiji 史記

si di 死地

Sima Qian 司馬遷

Sui (dynasty) 隋

Sun Bin 孫臏

Sunzi 孫子

Sunzi bingfa 孫子兵法

Tang (dynasty) 唐

Tang Taizong 唐太宗

Tangut (Dangxiang) 黨項

Tong dian 通典

Tuyuhun 吐谷渾

Wang Shichong 王世充

Wei 魏

wei Wei jiu Zhao 圍魏救趙 
David A. Graff

Weiliaozi 尉繚子

Wu Qi 吳起

Xingyang 滎陽

Xiongnu 匈奴

Yuwen Tai 宇文泰

Zhao 趙

Zhanguoce 戰國策

zhechongfu 折衝府

Zhou, Duke of 周公

Zichan 子產

Zuo zhuan 左傳 